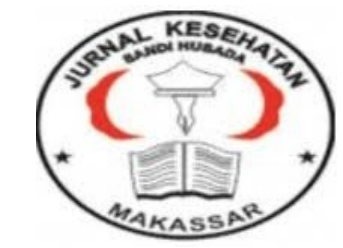

\author{
Jurnal Ilmiah Kesehatan Sandi Husada \\ hhttps://akper-sandikarsa.e-journal.id/JIKSH \\ Volume 9, Nomor 1, Juni 2020, pp; 585-590 \\ p-ISSN: 2354-6093 dan e-ISSN: 2654-4563 \\ DOI: $10.35816 /$ jiskh.v10i2.352
}

\title{
Efek Buah Kiwi (Actinidia Deliciosa) Sebagai Pengobatan Luka Bakar Derajat II
}

Effects of Kiwifruit (Actinidia Deliciosa) as a treatment Degree II Burns

Agung Assirri

Pendidikan Dokter, Fakultas Kedokteran, Universitas Lampung

\section{Artikel info \\ Artikel history:}

Received; Mei 2020

Revised: Juni 2020

Accepted; Juni2020

\begin{abstract}
Abstrak
Luka bakar merupakan cedera dengan morbiditas dan derajat cacat tertinggi di rumah sakit. Cedera luka bakar yang luas dan dalam masih merupakan penyebab utama kematian. Anak- anak dan orang tua beresiko untuk mengalami luka bakar yang lebih dalam karena lapisan kulit dermis mereka lebih tipis. Luka bakar dapat disebabkan sentuhan panas, arus listrik atau bahan kimia yang mengenai kulit, mukosa, dan jaringan. Prevalensi dari 19972002 terdapat 17.237 anak di bawah 5 tahun mendapat perawatan di gawat darurat di 100 rumah sakit di Amerika. Prevalensi kejadian luka bakar di Indonesia sebesar 2,2\%. Kasus luka bakar dapat mengalami berbagai macam komplikasi yang fatal termasuk diantaranya kondisi syok, infeksi, ketidakseimbangan cairan elektrolit dan distress pernapasan. Selain komplikasi yang berbentuk fisik, luka bakar dapat juga menyebabkan distress emosional (trauma) dan psikologis yang berat dikarenakan cacat akibat luka bakar dan bekas luka. Obat-obatan yang berkhasiat untuk menangani luka bakar yang telah banyak dikenal selama ini, seperti silver sulfadiazine, bacitracin dan mafenide acetate adalah agen anti mikrobial. Kiwi (Actinidia deliciosa) adalah tanaman yang yang banyak mengandung senyawa fitokimia seperti flavonoid, triterpenoid, dan quinone. Selain itu buah kiwi memiliki kadar antioksidan dan nilai gizi yang tinggi, kaya akan vitamin $C$, serat, kalsium, zat besi, fosfor dan kalium, serta kandungan fenolik yang lebih tinggi dari stroberi, jambu batu, pepaya dan belimbing yang dapat mengobati luka hingga luka bakar derajat dua.
\end{abstract}

\begin{abstract}
Burns are injuries with the highest morbidity and disability in the hospital. Extensive and deep burn injuries are still the main cause of death. Children and parents are at risk for deeper burns because their dermis is thinner. Burns can be caused by touches of heat, electrical current or chemicals that affect the skin, mucosa, and tissues. Prevalence from 1997-2002 there were 17,237 children under 5 years received emergency treatment at 100 hospitals in America. The prevalence of burns in Indonesia is $2.2 \%$. Burns can give fatal complications including shock conditions, infections, electrolyte fluid imbalances and respiratory distress. In addition to physical complications, burns can also cause severe emotional (trauma) and psychological distress due to disability and scars.
\end{abstract}


Effective drugs for treating burns that have been widely known so far, such as silver sulfadiazine, bacitracin and mafenide acetate are anti-microbial agents. Kiwi (Actinidia deliciosa) is a plant that contains many phytochemical compounds such as flavonoids, triterpenoids, and quinone. In addition, kiwifruit has high levels of antioxidants and nutritional value, rich in vitamin C, fiber, calcium, iron, phosphorus and potassium and a higher phenolic content than strawberries, guava, papaya and starfruit which can treat wounds to second degree burns.

\begin{tabular}{lr}
\hline Keywords: & $\begin{array}{r}\text { Corsponden author: } \\
\text { Luka bakar; }\end{array}$ \\
Kiwi; & Email: assirriagung@gmail.com \\
Pengobatan; & artikel dengan akses terbuka dibawah lisensi BCC BY NC ND-4.0
\end{tabular}

\section{Pendahuluan}

Departemen Kesehatan RI (2010), menyatakan bahwa prevalensi kejadian luka bakar di Indonesia sebesar 2,2\%. Luka bakar merupakan cedera dengan morbiditas dan derajat cacat tertinggi di rumah sakit. Cedera luka bakar terutama pada luka bakar yang dalam dan luas masih merupakan penyebab utama kematian dan ketidakmampuan jangka panjang. Anak- anak dan orang tua beresiko untuk mengalami luka bakar yang lebih dalam karena lapisan kulit dermis mereka lebih tipis. Antara 1997-2002 terdapat 17.237 anak di bawah 5 tahun mendapat perawatan di gawat darurat di 100 rumah sakit di Amerika. Luka bakar dapat disebabkan sentuhan panas, arus listrik atau bahan kimia yang mengenai kulit, mukosa, dan jaringan. Kasus luka bakar dapat mengalami berbagai macam komplikasi yang fatal termasuk diantaranya kondisi shock, infeksi, ketidakseimbangan cairan elektrolit (inbalance elektrolit) dan masalah distress pernapasan. Selain komplikasi yang berbentuk fisik, luka bakar dapat juga menyebabkan distress emosional (trauma) dan psikologis yang berat dikarenakan cacat akibat luka bakar dan bekas luka (Gravante dan Montone, 2010).

Obat-obatan yang berkhasiat untuk menangani luka bakar yang telah banyak dikenal selama ini, seperti silver sulfadiazine, bacitracin dan mafenide acetate adalah agen anti mikrobial. Bryant dan Ruth (2015) menjelaskan fokus pada manajemen luka, setidaknya dua puluh tahun terakhir, lebih kepada sediaan yang mengandung silver karena telah dikenal memiliki karakteristik antimikroba yang unggul berhasil menurunkan insiden sepsis luka bakar. Hal ini terkait dengan kemampuan silver dalam membunuh mikroba cukup tinggi. Oleh karena itu, silver sulfadiazine diterapkan menjadi terapi standar dalam pengobatan luka bakar. Kiwi (Actinidia deliciosa) adalah tanaman yang yang banyak mengandung senyawa fitokimia seperti flavonoid, triterpenoid, dan quinone. Selain itu buah kiwi memiliki kadar antioksidan dan nilai gizi yang tinggi, kaya akan vitamin C, serat, kalsium, zat besi, fosfor dan kalium, buah kiwi memiliki aktivitas antioksidan dan kandungan fenolik yang lebih tinggi dari stroberi, jambu batu, pepaya dan belimbing yang dapat mengobati luka hingga luka bakar derajat dua (Brunner dan Suddarth, 2010). 


\section{Metode}

Penelitian ini merupakan studi literature review, di mana peneliti mencari, menggabungkan inti sari serta menganalisis fakta dari beberapa sumber ilmiah yang akurat dan valid. Studi literatur menyajikan ulang materi yang diterbitkan sebelumnya, dan melaporkan fakta atau analisis baru. Tinjauan literatur memberikan ringkasan berupa publikasi terbaik dan paling relevan. kemudian membandingkan hasil yang disajikan dalam makalah.

\section{Hasil Dan Pembahasan}

Luka bakar harus segera ditangani agar proses inflamasi dapat diredam, mencegah timbulnya Systemic Inflammatory Response Syndrome (SIRS), Multi-system Organ Dysfunction Syndrome (MODS), dan sepsis serta mencegah timbulnya parut hipertrofik dan kontraktur. Perlu diketahui bahwa SIRS dan MODS merupakan penyebab utama tingginya angka mortalitas pada pasien luka bakar maupun trauma berat lainnya. Dalam penelitian-penelitian yang dilaporkan di kepustakaan, SIRS dan MODS keduanya menjadi 81\% kematian pasca trauma; dan dapat dibuktikan pula bahwa SIRS sendiri mengantarkan pasien pada MODS. Luka biasa terjadi dalam kehidupan sehari-hari. Proses penyembuhan luka diklasifikasikan ke dalam 5 fase, yaitu fase selular (granulasi), penyempitan daerah luka (konstraksi luka), deposisi kolagen (kolagenasi), penutupan epitel (epitelisasi), remodelling luka bakar (cicatrisation). Fase-fase ini berjalan bersamaan, tetapi tidak saling bergantung satu sama lain (Hamid et al, 2010).

Buah kiwi (Actinidia deliciosa), disebut juga Chinesegooseberry, sejenis beri dari China. Berbentuk bulat lonjong, bewarna cokelat dengan bulu-bulu halus pada kulit buahnya. Buah asal China ini diperkenalkan ke Selandia Baru pada tahun 1906 dan jenisnya mulai dikembangkan hingga akhirnya Selandia Baru terkenal sebagai negara penghasil kiwi, saat ini terdapat sekitar 10 jenis kiwi yang ditanam hamper di seluruh dunia, termasuk di Amerika Serikat, Prancis, Italia, Spanyol, Israel, Chili, Australia, Afrika Selatan dan Rusia. Buah kiwi memiliki keuntungan yang menjajikan baik bagi ilmu medis pengobatan dan juga dalam hal finansial bagi petani buah di Indonesia. Namun ada kendala yang dihadap, yaitu buah kiwi yang bukan buah nasional Indonesia, pasokan terbesar berasal dari impor, dan harga dari buah kiwi sendiri terbilang cukup mahal dibandingkan buah sejenisnya (Bukowski et al, 2016). Buah kiwi memiliki kadar antioksidan dan nilai gizi yang tinggi, kaya akan vitamin C, serat, kalsium, zat besi, fosfor dan kalium, selain itu buah kiwi merupakan sumber flavonoid yang baik. Buah kiwi memiliki aktivitas antioksi dan dan kandungan fenolik yang lebih tinggi dari stroberi, jambu batu, pepaya dan belimbing. Antioksidan pada buah kiwi antara lain vitamin C, klorofil a dan b, $\beta$ karoten, dan beberapa senyawa fenolik. Beberapa efek klinis dari kandungan buah kiwi seperti asam askorbat (sebagai scavenger), agen antibakterial, dan actinidin (enzim pengurai protein yang poten) telah dilaporkan dalam berbagai literatur. Buah kiwi mengandung antibacterial, agen scavenger dan enzim proteolitik, yang mungkin meningkatkan penyembuhan luka dan penggunaan senyawa alami yang mengurangi munculnya efek samping dibandingkan menggunakan substansi kimia (Moenadjat dan Yefta, 2010; Mohajeri, Masoudpour dan Heidarpour, 2010).

Penyembuhan luka, kekuatan dan integritas dari jaringan ditentukan oleh akumulasi kolagen. Rantai kolagen hanya dapat dibentuk jika prolin dan lisin terhidroksilasi di ribosom. Pada sintesis ini, asam askorbat digunakan sebagai kofaktor pada konversi residu prolin menjadi hidroksiprolin. Akibatnya, asam askorbat menstimulasi sekresi 
prokolagen dan defisiensi asam askorbat melemahkan sintesis kolagen. Asam askorbat telah dilaporkan dapat meningkatkan deposisi kolagen dan kekuatan tegangan dari perbaikan luka. Buah kiwi, merupakan salah satu buah yang popular, mengandung senyawa asam askorbat yang paling tinggi. Pada studi yang dilakukan oleh Iran dkk. kekuatan tegangan pada penyembuhan luka yang dirawat dengan buah kiwi dikarenakan tingginya kadar asam askorbat dalam buah kiwi.10

Vaskularisasi yang baik ke jaringan yang mengalami keruskan berperan vital dalam proses pemulihan jaringan. Pada penelitian yang dilakukan Mohajeri Masoudpour dan Heidarpour (2010), ditemukan bahwa pasien yang diterapi menggunakan balutan buah kiwi pada luka didapatkan vaskularisasi yang lebih baik. Hasil tersebut mungkin disebabkan oleh agen-agen angiogenik yang terkandung di dalam buah kiwi yang dapat memodulasi proses angiogenesis sehingga terbentuk neovaskularisasi yang membuat vaskularisasi pada luka menjadi lebih baik. Namun hingga saat ini belum diketahui kandungan spesifik apakah yang membuat proses angiogenesis ini berjalan lebih baik. Penelitian oleh Mohajeri et al (2010), didapatkan peningkatan drastis proses granulasi, epitelisasi dan pembentukan kolagen pada proses penyembuhan luka diabetes dalam gambaran histologinya. Peningkatan tersebut berimplikasi pada proses inflamasi yang berkurang pada lokasi terbentuknya luka (Sunarjono dan Hendro, 2010).

Mengingat infeksi pada luka merupakan masalah yang sering terjadi pada pasien dengan kaki luka diabetes, kontrol terhadap terjadinya infeksi sangatlah penting. Penelitian sebelumnya menunjukkan bahwa terdapat antibakteri signifikan yang terkandung dalam buah kiwi. Ternyata efek dari protein CPs (actinidin) dengan konsentrasi tinggi dalam buah kiwi dapat berperan sebagai antibakteri, antifungal, dan antiinsekta yang mencegah terjadinya infeksi. Bahkan lebih khususnya terhadap bakteri gram positif dan negative (Mishra et al, 2010). Permasalahan selama terapi menggunakan obat herbal adalah efek yang tidak dapat diperkirakan seperti reaksi alergi. Namun, dari berbagai studi pada mencit, tidak didapatkan efek samping yang berarti bagi pasien yang diterapi menggunakan buah kiwi. Berdasarkan peranan yang cukup besar dari buah kiwi yang diantaranya membantu proses debridement dan pelepasan jaringan parut tanpa merusak proses penyembuhan, perbaikan angiogenesis, epitelisasi dan granulasi, serta efeknya terhadap penurunan ukuran luka menunjukkan bahwa buah kiwi dapat menjadi pilihan pengobatan yang menjanjikan bagi upaya terapi luka bakar (Pisoschi et al, 2015). Penelitian lain yang dilakukan oleh Alim et al (2019) aktivitas antibakterial yang lebih signifikan ketika menggunakan balut buah kiwi dibandingkan dengan pemberian sulfadiazine silver pada hewan yang dicobakan. Mohajeri dkk mengindikasikan bahwa pembalutan dengan buah kiwi mempercepat penyembuhan luka pada luka bakar dan mereka menyatakan efek ini berasal dari antibakterial yang dramatis. Selain itu, pada penelitian lainnya, Mohajeri menunjukkan kemampuan buah kiwi dalam membersihkan debris jaringan dan mengatasi jaringan parut tanpa menghasilkan efek yang merugikan bagi proses penyembuhan, peningkatan angiogenesis, epitelisasi dan granulasi serta efek untuk menurunkan ukuran luka tersebut (Guo dan dipietro, 2010).

Penggunaan buah kiwi sebagai obat luka bakar dalam masyarakat haruslah praktis dan nyaman. Oleh karena itu, perlu dibuat suatu bentuk sediaan penyembuh luka yang nyaman, aman, dan efektif. Berbagai bentuk sediaan yang ditujukan untuk luka dapat digunakan, salah satunya adalah sediaan gel. Penggunaan gel membantu mempercepat proses penyembuhan dengan menciptakan lingkungan lembab yang akan mengurangi jaringan nekrosis melalui pembentukan sel apoptosis yang diperlukan dalam penanganan 
luka. Keberhasilan penatalaksanaan luka di antaranya adalah meminimalkan formasi bekas luka dan menurunkan jumlah jaringan nekrosis yang diproduksi selama proses penyembuhan luka. Gel sangat ideal digunakan sebagai penutup luka karena terasa dingin di permukaan luka, menurunkan rasa sakit, dan meningkatkan penerimaan konsumen (Zawawy, 2015). Gel mampu memberikan efek topikal yang baik dan memiliki daya sebar yang baik sehingga dapat bekerja langsung pada lokasi yang sakit dan tidak menimbulkan bau tengik. Selain itu, gel mampu membuat lapisan film sehingga mudah dicuci dengan air (Liu et al, 2018).

\section{Simpulan Dan Saran}

Potensi yang besar dari buah kiwi dapat membantu proses debridement dan pelepasan jaringan parut tanpa merusak proses penyembuhan, perbaikan angiogenesis, epitelisasi dan granulasi, serta efeknya terhadap penurunan ukuran luka menunjukkan bahwa buah kiwi dapat menjadi pilihan pengobatan yang menjanjikan bagi upaya terapi luka bakar.

\section{Daftar Rujukan}

Alim, Li, Nisar, Ren, Zhai, Pang et al. (2019). Antioxidant, antimicrobial, and antiproliferative activity-based comparative study of peel and flesh polyphenols from Actinidia chinensis. Food Nutr Res.

Https://doi: 10.29219/fnr.v63.1577

Brunner dan Suddarth. (2010). Textbook of Medical Surgical Nursing (12th ed.). USA: Lippincott.

Bryant dan Ruth. (2015). Acute \& Chronic Wounds: Current Management Concepts. Five Edition. Mosby Elsevier: United States of America.

Bukowski, Budd, Gibbons, Bauer, Childs dan Finkle et al. (2016). Phase I trial of subcutaneous recombinant macrophage colony-stimulating factor: clinical and immunomodulatory effects. Journal of Clinical Oncology. https:// DOI: 10.1200/JC0.1994.12.1.97.

Departemen Kesehatan RI. (2010). Tim Pusat Data dan Informasi Kementrian Kesehatan RI. Jakarta: Departemen Kesehatan.

Gravante dan Montone. (2010). A retrospective anaysis of ambulatory burn patients: focus on wound dressing and healing times. Ann R Coll Surgical England. https:// doi: 10.1308/003588410X12518836439001

Guo dan DiPietro. (2010). Factors Affecting Wound Healing. J Dent Res. https:// doi: 10.1177/0022034509359125

Hamid, Aiyelaagbe, Ameen dan Lawal. (2010). Antioxidants: Its medicinal and pharmacological Applications. African Journal of Pure and Applied Chemistry. 4 (8), pp 142-151.

Julkunen-Tiitto. (2014). Phenolics Constituens in the Leaves of Northern Willows: Methods for the Analysis of Certain Phenolics. J. Agric. Food Chem. 2014;33: 213217.

Liu, Wang, Li, Qin, Wang, Yang et al. (2018). A functional chitosan-based hydrogel as a wound dressing and drug delivery system in the treatment of wound healing. RSC Advances. https://doi10.1039/C7RA13510F

Moenadjat dan Yefta. (2010). Luka Bakar-Pengetahuan Klinik Praktis. Balai Penerbit FKUI: Jakarta.

Mohajeri, Masoudpour dan Heidarpour. (2010). The effect of dressing with fresh kiwifruit 
on burn wound healing. Surgery. https:// doi: 10.1016/j.surg.2010.02.013

Neeraj Mishra, Dubey, dan Singh. (2010). Antimicrobial, Antioxidant and Chemopreventive Potential of Vitamin C in Rich Fruits. International Journal of Applied Biology and Pharmaceutical Technology. 11 (3), pp 1-10.

Pisoschi, Cimpeanu, dan Predoi. (2015). Electrochemical Methods for Total Antioxidant Capacity and its Main Contributors Determination: A review. Journal of chemistry. https://doi: https://doi.org/10.1515/chem-2015-0099

Sentana dan Aso. (2010). Health Secret of Kiwifruit. Jakarta: PT ELex Media Komputindo.

Sunarjono dan Hendro. (2010). Berkebun 21 Jenis Tanaman Buah. Jakarta: Penebar Swadaya.

Zawawy. (2015). Antioxidant, Antitumor, Antimicrobial Studies and Quantitative Phytochemical Estimation of Ethanolic Extracts of Selected Fruit Peels. Journal CMAS.

Http://doi: 10.17352/jbm.000013 